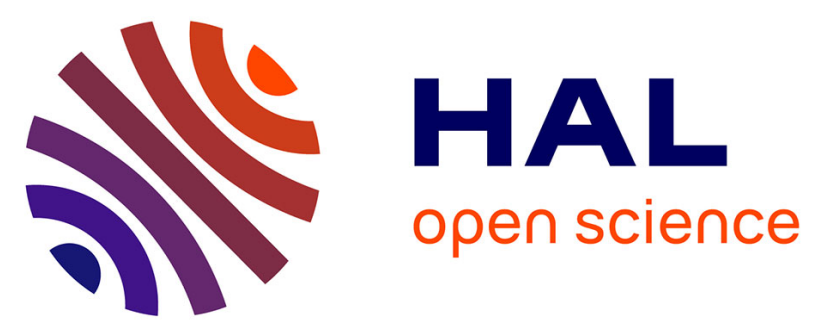

\title{
Material Characteristics, Hydraulic Properties, and Water Travel Time through the Heterogeneous Vadose Zone of a Cenozoic Limestone Aquifer (Beauce, France)
}

Arnaud Isch, Carlos Aldana, Yves Coquet, Mohamed Azaroual

\section{- To cite this version:}

Arnaud Isch, Carlos Aldana, Yves Coquet, Mohamed Azaroual. Material Characteristics, Hydraulic Properties, and Water Travel Time through the Heterogeneous Vadose Zone of a Cenozoic Limestone Aquifer (Beauce, France). EGU General Assembly 2020, May 2020, Online, France. 10.5194/egusphere-egu2020-5862 . hal-03554433

\section{HAL Id: hal-03554433 \\ https://hal.science/hal-03554433}

Submitted on 3 Feb 2022

HAL is a multi-disciplinary open access archive for the deposit and dissemination of scientific research documents, whether they are published or not. The documents may come from teaching and research institutions in France or abroad, or from public or private research centers.
L'archive ouverte pluridisciplinaire HAL, est destinée au dépôt et à la diffusion de documents scientifiques de niveau recherche, publiés ou non, émanant des établissements d'enseignement et de recherche français ou étrangers, des laboratoires publics ou privés.

\section{(c)(1)}

Distributed under a Creative Commons Attribution| 4.0 International License 
EGU2020-5862

https://doi.org/10.5194/egusphere-egu2020-5862

EGU General Assembly 2020

(c) Author(s) 2022. This work is distributed under

the Creative Commons Attribution 4.0 License.

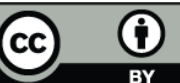

\title{
Material Characteristics, Hydraulic Properties, and Water Travel Time through the Heterogeneous Vadose Zone of a Cenozoic Limestone Aquifer (Beauce, France)
}

\author{
Arnaud Isch ${ }^{1}$, Carlos Aldana ${ }^{1}$, Yves Coquet ${ }^{2}$, and Mohamed Azaroual ${ }^{1}$ \\ ${ }^{1}$ UMR 7327 ISTO, CNRS, Université d'Orléans, BRGM, 45071 Orléans, France \\ ${ }^{2}$ UMR 1402 ECOSYS, AgroParisTech, INRA, 78850 Thiverval-Grignon, France
}

\begin{abstract}
Water retention and hydraulic conductivity are the most important properties governing water flow and solute transport in unsaturated porous media. However, transport processes in the vadose zone (VZ) are still not completely understood, in spite of their importance for the preservation and management of aquifers, especially in the geographic zones under intensive agriculture. This study has been carried out as part of the construction of the O-ZNS platform (Observatory of transfers in the vadose zone). This platform aims to integrate observations over a wide range of spatial and temporal scales thanks to a large access well (depth-20 $\mathrm{m}$ \& diameter $-4 \mathrm{~m}$ ) surrounded by several boreholes in order to combine broad characterization and focused monitoring techniques.
\end{abstract}

Three cored boreholes have been drilled in Spring 2017. Structural and mineralogical analyses were carried out for four types of materials sampled throughout the entire VZ profile ( $20 \mathrm{~m}$ depth) including soft sediments (soil, marl and sand) and fractured limestone rock. Hydraulic properties $(q(h)$ and $K(h))$ were measured on representative core samples by means of a triaxial system used by applying the multistep outflow method. Simulations were then made using HYDRUS-1D to simulate water flow and bromide (conservative tracer) transport over 50 years using meteorological and water table level data.

The results brought valuable information about factors contributing to the heterogeneity of hydraulic properties within the VZ. For the applied matric heads (from 0 to $-1000 \mathrm{~cm}$ ), the water content and hydraulic conductivity of (i) the soft materials (9 samples) ranged from 0.173 to $0.485 \mathrm{~cm}^{3} / \mathrm{cm}^{3}$ and from $1.26 .10^{-5}$ to $2.41 \mathrm{~cm} / \mathrm{d}$, respectively ; (ii) the hard materials (5 samples) ranged from 0.063 to $0.340 \mathrm{~cm}^{3} / \mathrm{cm}^{3}$ and from $8.54 .10^{-5}$ to $1.82 \mathrm{~cm} / \mathrm{d}$, respectively. The shape of the water retention and hydraulic conductivity curves obtained for the soft sediments is strongly related to the physical properties of the material but also to the proportion and the nature of clay minerals. The soil material displayed the largest average water retention capacity due to the presence of smectite and kaolinite, indicating weathering and matrix transformation. The water retention capacity of the marl and sand materials was lower due to higher content in palygorskyte and calcite. The limestone rock materials displayed an important heterogeneity in their hydraulic properties. Mineralogical analysis helped understanding water flow pathways within the limestone 
aquifer. The non-altered matrix, that seemed impermeable at first sight, presented few thin microfractures where water probably accumulates. The altered matrix showed microfractures where water has circulated and calcite has been replaced by phyllosilicates, thus increasing the water retention capacity. Natura macrofractures observed at dm-scale showed the presence of iron oxides which highlighted an exposure to high water flow. Simulations made using HYDRUS-1D allowed a first estimation of water and solutes travel time through this highly heterogeneous vadose zone. The results highlighted transfer time of between 25 to 35 years for the bromide to reach water table. The differences observed between the three cored boreholes were mainly due to the heterogeneity of the marl materials located between 1 and $7 \mathrm{~m}$ deep. 